\section{SALVARSAN IN PERNicious aNaEmia.}

BY

EDMUND HOBHOUSE, M.D.; F.R.C.P.,

PHYSICIAN, SUSSEX COENTY HOSPITAL, BRIGHTON.

'As all evidence as to new treatment is of value, brief notes of the following case may be of interest. I believe it to be the first case treated on these lines south of the Tweed, and I publish it with the kind concurrence of my friends, Messis. Dodd and Clarke, under whose care it was. I saw the patient first on May 23rd, 1912.

She had been very anamic for more than a year and exceedingly ill in the previous summer, but had improved under large doses of arsenic, and been fairly well during the winter. Her blood picture in October, 1911, showed no signs of pernicious anaemia. On May 23 rd she was very ill with daily fever up to about $101^{\circ} \mathbf{F}$., almost unable to sit up or take nourishment, with rery loud haemic muirmurs all over the cardiac area; her colour was the characteristic lemon yellow. A film showed colour was the characteristic lemon yellow. A film showed was injected intramuscularly. Within three days benefit was apparent, though local pain was severe for about a week. In four days the murmurs had almost disappeared, and the patient was much stronger. Blood examination on June 4th showed a distinct improvement.

On June 14th the improvement had continued, and the same lose was again injected in the buttock; this was followed by a sharp reaction; the temperature rose to $101^{\circ} \mathrm{F}$. The patient looked exceedingly ill; the pallor and haemic murmurs returned, and she developed a large patch of dry pleurisy over the right back. This condition lasted a few days, when the fever slowly subsided and uninterrupted recovery set in." The blood examinations on July 2nd and 19th and August 7th (see table) showed a rapid change in the blood picture and the chan so the a rapice and the change in the appearance remark able. She got

The blood reports speak more eloquently than any words, and I will only make two or three remarks further.

1. The rapid fall of temperature after the first injection suggests very strongly the destruction of some virus.

2. In another case I should certainly postpone the second injection as long as improvement was going on, for a week or two.

3. It is difficult to say to what the severe reaction after the second injection was due, possibly hypersensitization. $I$ have come across pleurisy in anotlier case after salvarsan.

4. It reinains to be seen, I think, whether intravenous is equal to intramuscular injections where prolonged action is desirable, though the latter has undoubted advantageș.

5. The results are so striking that though we know all cases do not react in the same way this treatment should always have a trial.

We have to thank Dr. Byrom Bramwell for sending us an advance copy of his paper, which I had the good fortune to héar at a meeting of the Association of Physicians in Glasgow in April, and also Dr. Galt for his kindness in taking much trouble about the blood examinations.

\begin{tabular}{l|c|c|c|c}
$\begin{array}{c}\text { Date. } \\
\text { : }\end{array}$ & Red Cells. & Leucocytes. & Haemoglobin. & $\begin{array}{c}\text { Coloux } \\
\text { Index. }\end{array}$ \\
\hline 1. Oct. 3, 1911 & $1,425,000$ & 5,550 & $\begin{array}{c}\text { Per Cent. } \\
30.0\end{array}$ & $\begin{array}{c}\text { Per Cent. } \\
1.0\end{array}$ \\
2. May 24, 1912 & 800,000 & 9,050 & 18.0 & 1.0 \\
3. June 4, 1912 & 976,000 & 9,150 & 36.0 & 1.7 \\
4. Ju1y 2, 1912 & $2,372,000$ & 6,900 & 63.0 & 1.19 \\
5. July 19, 1912 & $3,792,000$ & 8,300 & 90.0 & 1.0 \\
6. Aug. 7,-1912 & $4,160,000$ & 4,950 & 96.0 & 1.0 \\
7. Oct. 8, 1912 & $4,704,000$ & 6,300 & 110.0 & 1.05 \\
\hline
\end{tabular}

Notes.

1. No anisocytosis or poikolocytosis and no nucleated reds; rather 1. No anisocytosis or poikolocytosis and

2. Marked polychromstophilia and distinct though not extreme poikilocytosis and anisocytosis. Nucleated red cells common: 2 megaloblasts and 8 normoblasts counted with 200 leucocytes. The type is one of a true megaloblastic pernicious anaemia.

3. Marled polychromatophilia, slight poikilocytosis and anisocy tosis ; 4 megaloblasts and 1 normoblast in a very large number of fields.

4. Slight polychroma tophilia. No anisocy tosis or poikilocytosis. No nucleated reds after special search.

5;6, and 7. Normal, except for the decreasing deficiency in red cells. The only point which is not absolutely satisfactory is that the colour fact that she went on taking largish doses of iron for some time.

Salvarsan 0.3 gram was injected on May 31 st and June 14th.

\section{The Science Committee}

OF THE

\section{船ritish Atteriral Assuriation.}

\section{THE CYTOLOGY OF THE BLOOD IN PASSIVE IMMUNITY.}

By J. SHOLTO C. DOUGLAS, M.A., D.M.

(From the Pathological Departments of the Universities of Oxford

[ABSTRACT.]

A series of figures obtained by determining the numbers of cells present in the peripheral blood of man and rabbits before and after the injection of various samples of serum have been analysed. The serums used were, in the case of man, normal horse, diphtheria antitoxin, and antistreptococcic; and for rabbits, normal and agglutinating rabbit and goat, diphtheria antitoxin (horse) and antistreptococcic (horse). As far as possible the figures obtainet during the control periods were subjected to the method of least square, the resultant figure giving a measure either of any error due to the various manipulations to which the blood samples were subjected for securing the counts of corpuscles or of any variation in their numbers arising from day to day and-due to natural causes. These may be termed respectively the "Mean Deviation of the Experiment," when the differences between counts on blood samples collectèd practically simultaneously from the same animal are considered, or the "Mean Daily Variation," where the differences observable from day to day are analysed. The advantage accruing from the linowledge of these is that the mathematical chances in favour of any alterations observed in the blood counts being due to the experimental injection and not to a natural érror or variation can be ascertained.

In some instances, when the rabbits had been subjected to daily haernorrhage, the method of least square could not be used in the examination of the numbers of corpuscles, and another procedure had to be adopted. This consisted in comparing the average number of cells during the control period with the average number present on the days subsequent to the injections of serums. In the case of rabbits a fresh animal: was used for each injection of any sample of serum, which took place by the subcutaneous, intravenous, or intraperitoneal routes. For man one individual served for all the inocnlations of serums which were performed hypodermically.

The results of a consideration of the numbers of blood corpuscles in the peripheral blood during the control and during the experimental period may be summarized as follows :

1. The method of least "squares can be satisfactorily applied to the analysis of the deviations and variations in a series of enumerations of the blood corpuscles, and of estimations of haemoglobin in the blood of man and of rabbits.

2. The "mean deviation of the experiment" for a series of estimations of haemoglobin and blood corpuscles in rabbits is independent of the hour of day and of small haemorrhages.

3. The "mean deviation of the experiment" is, in rabbits, greater for leucocytes than for red cells, and for red corpuscles than for haemoglobin, being on the average in this series of experiments 7.73 per cent. for leucocytes, 3.81 per cent. for red cells, and 1.28 per cent. for haemoglobin.

4. The "mean deviation of the experiment".was larger in a series of animals examined immediately they reached the laboratory than in another series which had... been allowed sufficient time to become accustomed to their new environment."

5. The "mean daily variation" for the haemoglobin, red cells, and leucocytes was smaller in rabbits which had been kept some days in the laboratory than in those examined inmediately they had been procured from the market.

6. The "mean daily variation" for blood cells becomes smaller as the day advances in the case of rabbits, and can 